\title{
The race to prevent the extinction of South Asian vultures
}

\author{
DEBORAH J. PAIN, CHRISTOPHER G.R. BOWDEN, ANDREW A. \\ CUNNINGHAM, RICHARD CUTHBERT, DEVOJIT DAS, MARTIN GILBERT, \\ RAM D. JAKATI, YADVENDRADEV JHALA, ALEEM A. KHAN, VINNY \\ NAIDOO, J. LINDSAY OAKS, JEMIMA PARRY-JONES, VIBHU PRAKASH, \\ ASAD RAHMANI, SACHIN P. RANADE, HEM SAGAR BARAL, KALU RAM \\ SENACHA, S. SARAVANAN, NITA SHAH, GERRY SWAN, DEVENDRA \\ SWARUP, MARK A. TAGGART, RICHARD T. WATSON, MUNIR Z. VIRANI, \\ KERRI WOLTER and RHYS E. GREEN
}

\begin{abstract}
Summary
Gyps vulture populations across the Indian subcontinent collapsed in the 1990 and continue to decline. Repeated population surveys showed that the rate of decline was so rapid that elevated mortality of adult birds must be a key demographic mechanism. Post mortem examination showed that the majority of dead vultures had visceral gout, due to kidney damage. The realisation that diclofenac, a non-steroidal anti-inflammatory drug potentially nephrotoxic to birds, had become a widely used veterinary medicine led to the identification of diclofenac poisoning as the cause of the decline. Surveys of diclofenac contamination of domestic ungulate carcasses, combined with vulture population modelling, show that the level of contamination is sufficient for it to be the sole cause of the decline. Testing on vultures of meloxicam, an alternative NSAID for livestock treatment, showed that it did not harm them at concentrations likely to be encountered by wild birds and would be a safe replacement for diclofenac. The manufacture of diclofenac for veterinary use has been banned, but its sale has not. Consequently, it may be some years before diclofenac is removed from the vultures' food supply. In the meantime, captive populations of three vulture species have been established to provide sources of birds for future reintroduction programmes.
\end{abstract}

\section{Introduction}

Eight vulture species in the genus Gyps are widely distributed across Europe, Asia and Africa. They are all obligate scavengers, feeding primarily on the carcasses of large ungulates and nesting and roosting, often colonially, on cliffs or in trees. They use energetically economical soaring flight to travel long distances from nests and roosts in search of ungulate carcasses (Houston 1974, Ruxton and Houston 2004). Gyps vultures are believed to have evolved in parallel with large herds of migratory ungulates, feeding on the remains of sick, injured and depredated individuals (Mundy et al. 1992). These herds have disappeared from most of the world range of Gyps vultures, remaining only in some of the larger protected areas. However, the food supply formerly provided by wild ungulates was replaced by traditional farming practices in some areas. For example, in the Spanish Pyrenees, transhumance pastoralism, in which herds of domestic ungulates graze the high mountain pastures in the summer and are shepherded to the lowlands in the winter, provided a food supply for Eurasian Griffon Vultures 
Gyps fulvus from the $18^{\text {th }}$ to mid $20^{\text {th }}$ centuries, although these practices have recently declined dramatically across Europe (Pain and Pienkowski 1997).

In spite of these changes in food supply, the Cape Griffon Gyps coprotheres of southern Africa was the only member of the genus considered to be in danger of global extinction until the late 1990s. This species is believed to have been affected by multiple threats (BirdLife International 2007). It was then recognised that populations of vultures endemic to South Asia were declining rapidly across the Indian subcontinent for unknown reasons. This led to three species, the Oriental White-backed Vulture Gyps bengalensis (OWBV), the Long-billed Vulture G. indicus (LBV) and the Slender-billed Vulture G. tenuirostris (SBV) being listed by IUCN as 'Critically Endangered'. In this paper, we describe recent research to determine the causes of the population declines and to identify ways to prevent the extinction of these species.

\section{Population trends of Gyps vultures outside the Indian subcontinent}

In southern Africa, populations of the endemic Cape Griffon have declined slowly, principally because of accidental poisoning, collision and electrocution, food stress and disturbance (BirdLife International 2007). In West Africa, vultures have undergone a large decline over the last 35 years, with national parks being the only areas not showing significant declines (Thiollay 2006). Many factors are thought to have contributed to these relatively recent declines, including habitat destruction or degradation, inadvertent poisoning from baits placed to kill other species, the capture of birds for local medicinal purposes or the wild bird trade. However, the disappearance of wild large ungulates because of exploitation for bush meat and reduced availability of the carcasses of domestic livestock may have been important factors in the declines.

Two South Asian Gyps species, OWBV and SBV, were widespread and generally common in Southeast Asia (Cambodia, Vietnam, Laos, Thailand, Malaysia) at the beginning of the $2 \mathrm{O}^{\text {th }}$ century, but by the end of that century only a few small relict populations remained, primarily in Cambodia (Pain et al. 2003). Populations remain in Myanmar, but their numbers and status remain uncertain. Whilst factors like persecution may have played a role in the Southeast Asian declines, their main cause is believed to be food shortage. Overhunting resulted in a collapse in the populations of wild ungulates throughout the region (Srikosamatara and Suteethorn 1995, Duckworth et al. 1999, Hilton-Taylor 2000), and current livestock husbandry practices appear not to provide a sufficiently large food supply to support large populations (Pain et al. 2003).

\section{Collapse of Gyps vulture populations across the Indian subcontinent}

Although Gyps vulture populations were probably declining slowly in many parts of the world during the $2 \mathrm{O}^{\text {th }}$ century, a very different situation existed in India, Nepal and Pakistan. Here, large populations of OWBV and LBV remained until the 1990s. Large numbers of SBV, which was not distinguished as a separate species from LBV until recently (Rasmussen and Parry 2001), were also found in the northeastern parts of the subcontinent. Indeed, during the 1980s OWBV was thought likely to be the commonest large bird of prey in the world (Houston 1985). In India, Gyps vulture densities were so high in some areas that they were considered a hazard to aircraft (Grubh et al. 1990). This abundance was undoubtedly due to a plentiful food supply, in the form of the carcasses of domesticated ungulates. The keeping of livestock for milk production and as beasts of burden is common in rural areas across the Indian subcontinent and cattle are abundant in many towns and cities. Livestock numbers in India have exceeded 400 million since the 1980s, and reached 500 million in 2005 (ILC 2003, projection based on Animal Husbandry Statistics, Government of India). In large parts of the subcontinent, Hindu beliefs prohibit the slaughter of cows. When feral and domestic cows die a natural death they are left in the open in rural areas or disposed of in regulated carcass dumps around towns and cities. Skinners remove the hides from dead cattle for the leather industry, leaving vultures to scavenge the remaining soft tissue. As 
vulture populations benefited from the large amounts of food available, Indian society gained environmental health and other benefits from a free carcass disposal service. A flock of vultures can pick a cow carcass clean in a few hours, leaving little more than bones, that then dry rapidly in the sun, and are gathered by bone collectors for the fertilizer, gelatin and glue industries.

Whilst vultures feed primarily on large ungulates, they were also historically the key scavenger of the dead from the ancient Parsi religion, who lay their dead out in the open in enclosures or specially constructed 'Towers of Silence' (Pain et al. 1993). Vultures also have spiritual significance in Hindu mythology, as the vulture-king Jatayu died attempting to protect Sita, one of the principal characters of the Hindu epic 'Ramayana', from the demon king Ravana, while her husband Prince Rama was away hunting (Griffith 1870-1874).

The era of abundant Gyps vultures in the Indian subcontinent came to a sudden end in the 1990s. By the mid 1990s, newspapers in north India started publishing reports of vultures rapidly disappearing from carcass dumps. This was also documented by the Bombay Natural History Society (BNHS) whilst monitoring raptor numbers in Keoladeo National Park, a World Heritage Site at Bharatpur in eastern Rajasthan. In the mid 1980s, foraging vultures were numerous in the park. Several hundred pairs of OWBV nested within it and hundreds of pairs of LBV nested on cliffs at Bayana, not far outside. Between the late 1980s and mid to late 1990s, numbers of these two species found in the park had declined dramatically (Prakash 1999). Numbers of OWBV nests declined from 244-353 in the 1980s to none by the $1999 / 2000$ breeding season (Prakash 1999, Prakash et al. 2003). There was also anecdotal evidence of a general decline in vulture numbers throughout much of northern India during the late 199os. However, as there was little systematic bird monitoring, it was difficult to know whether reports reflected a truly nationwide decline, or isolated local changes. With support from the US Fish and Wildlife Service, BNHS had conducted nationwide raptor surveys in many parts of India between 1991 and 1993 using a repeatable road transect method (Samant et al. 1995). Surveys were carried out in, near, and along the routes travelled between protected areas. They covered large parts of north, west and eastern India. Unfortunately, not all Gyps vultures were counted because they were considered too numerous for this to be practicable. However, the surveyors counted vultures in any groups of five or more birds. BNHS, with support from the RSPB, repeated the road transect surveys in 2000. The results were dramatic. Both OWBV and LBV had almost disappeared from the areas surveyed. The population of OWBV across the surveyed range had declined by $96 \%$ between 1991-93 and 2000 and that of LBV by $92 \%$ (Prakash et al. 2003, 2005a, 2005b). It should be noted that these were minimum declines because individual vultures and those seen in small groups were counted in 2000, but not in 1991-1993. Subsequent counts on these and additional transects in 2002, 2003 and 2007 showed that OWBV and LBV continued to decline at an average rate of $44 \%$ (OWBV) and $16 \%$ (LBV) per year between 2000 and 2007 (Prakash et al. 2007). SBV was not distinguished from LBV until the 2002 count, when it was found to comprise less than $2 \%$ of the combined total of the LBV and SBV count (Green et al. 2004). Comparison of the 2002, 2003 and 2007 counts indicated that the population of SBV was declining in India about as rapidly as LBV (Prakash et al. 2007).

Following the results of the 2000 surveys, BNHS organised an international meeting in September 2000. The meeting, held in New Delhi, was supported by the Ministry of Environment and Forests (MoEF) of the Government of India and the RSPB, and was attended by national and international scientists, conservationists, and Indian government representatives. Among those represented was The Peregrine Fund, who joined forces with Washington State University and the Ornithological Society of Pakistan (OSP) to conduct vulture studies in Pakistan. Subsequent counts of breeding pairs of OWBV in nesting colonies in Punjab province, Pakistan, revealed a population decline at a rate of $50 \%$ per year between 2000 and 2003 (Gilbert et al. 2004, 2006, Green et al. 2004). This decline continued to extinction at several formerly large OWBV colonies in the province (Gilbert et al. 2006). This group also counted nesting LBV in Sind province, Pakistan (Gilbert et al. 2004), where numbers have declined by about twothirds between 2002 and 2006; an average annual decline rate of $25 \%$ per year (AVPP 2007). 
Hence, both in India and Pakistan, the rates of population decline of LBV, though rapid, are substantially slower ( $16 \%$ and $25 \%$ per year respectively) than the catastrophic decline rates for OWBV ( $44 \%$ and $50 \%$ ). The similarity of the recent average decline rates in the two countries is striking for both species. Backwards extrapolation of log-linear Poisson regression models of counts of vultures across India (for methods see Cuthbert et al. 2006a), and of vulture nests at Keoladeo National Park, suggest that the vulture declines probably started in the early to mid 1990s (Figure 1). Nest counts of OWBV by Bird Conservation Nepal (BCN) in eastern Nepal suggested similar rates of decline there, with 65 active nests found at Koshi in 2000-01 falling to just ${ }_{4} 4$ in 2002-03 (Baral et al. 2004).

The work of two main research groups was to prove crucial in the search for the cause of declines and solutions. BNHS led one group, initially comprising the Forest Department of the state government of Haryana, the RSPB, the Zoological Society of London (ZSL) and the National Birds of Prey Trust (NBPT), and later expanding to include a wide range of national and international organisations. The second group comprised The Peregrine Fund (TPF), Washington State University and the Ornithological Society of Pakistan (OSP). Whilst the BNHS consortium focussed largely on India, the TPF/OSP group conducted a complementary research programme in Pakistan, and BCN worked in Nepal in collaboration with both groups.

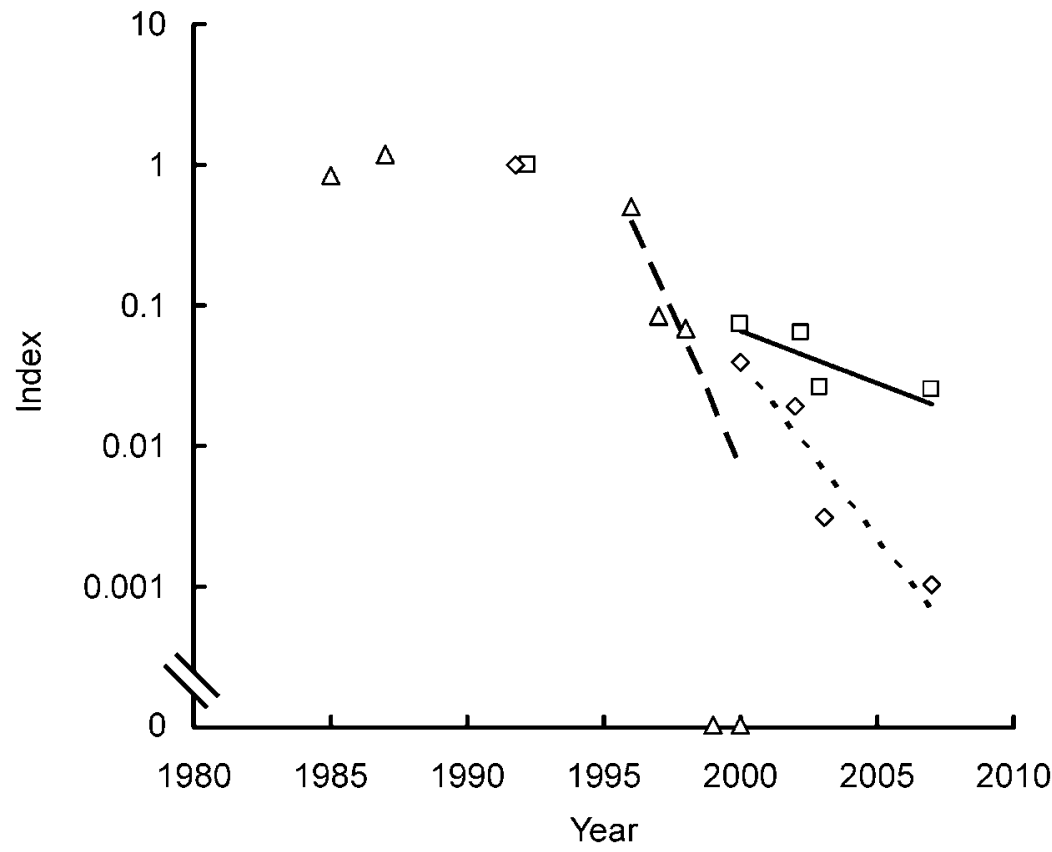

Figure 1. Population declines of Gyps vultures in India. Points show indices of population size from counts on a logarithmic scale, plotted against calendar year. This index represents the vulture population size as a proportion of the initial level $(=1)$. Triangles represent the number of active nests of Gyps bengalensis in Keoladeo National Park from Prakash et al. (2003) expressed as a proportion of the average in the 1980s. Indices of population size, relative to that in 1992, of G. bengalensis (diamonds) and G. indicus and G. tenuirostris combined (squares) in northern India were calculated from road transect count data as described by Prakash et al. (2007). Lines represent fitted log-linear regression models (dashed line $=$ G. bengalensis at Keoladeo, dotted line $=G$. bengalensis on road transects, solid line $=G$. indicus/tenuirostris on road transects). 


\section{Diagnosing the causes of the declines}

\section{Identifying demographic mechanisms}

Bird population declines involve changes in breeding success, the proportion of adults breeding, or survival rate, which are in turn brought about by external causes such as changes in nest site availability, food supply, disease or predation. Comparison of demographic rates and external influences on declining populations with those of stable populations of the same species is a frequently used and powerful method for diagnosing the cause of a population decline (Green 1995, 2002). However, this approach was not possible for vultures because, except for a relict population in Cambodia, all populations appeared to be declining rapidly throughout a huge area. Nonetheless, the very rapidity of the declines gave at least some clues about the demographic mechanism.

Like other large scavenging birds, Gyps vultures are usually long-lived. One bird was reported to live for 37 years in captivity and annual survival rates of wild large raptors are typically around $95 \%$ or higher (Newton 1979). An annual survival rate of $99 \%$ was reported for adult Eurasian Griffons, though this was for a reintroduced population receiving supplementary food and protection (Sarrazin et al. 1994). Adult survival rates have not been measured for Gyps vultures in the Indian subcontinent, but they too are likely to be high. If this is the case, then it is evident from their rapid rates that the demographic mechanism of the vulture declines in the Indian subcontinent must involve a substantial reduction in adult survival. Imagine that the adult survival rate of OWBV before the decline began was $95 \%$. Even if breeding success and immature survival were reduced so that no recruitment of young adults occurred, the adult population could not decline by more than $5 \%$ per year if adult survival remained at its predecline level. However, the observed rate of population decline is about $50 \%$ per year for this species. Such declines could only occur if there was abnormally high adult mortality. In 1985-86, when $>1,700$ OWBV were counted in Keoladeo National Park, only 14 birds ( 7 adults and 7 juveniles) were found dead. By contrast, by 1997-98, when only a few hundred OWBV remained, 73 adults and 1o juveniles were found dead (Prakash 1999). Prakash (1999) also found that the proportion of nests producing fledged young declined from $82 \%$ in $1985-1986(n=$ 244) to none in $1997-98(n=25)$. The causes of nest failure were unknown, but could have resulted from factors affecting eggs or chicks directly, high adult mortality affecting nest success, or a combination of the two. At the nearby breeding colony of LBV at Bayana, numerous vulture carcasses were found at the base of the cliffs.

In Pakistan the TPF/OSP research group made regular systematic searches for dead OWBV in and near the breeding colonies and roosts in their Punjab province study area (Gilbert et al. 2002). By comparing the number of birds found dead with the number counted at the beginning of a given time period, they were able to calculate minimum annual mortality rates. The minimum proportion of adults dying per year in 2001 was $15 \%$ and the proportion for adults and sub-adults combined was $26 \%$. Mortality may have been considerably higher than this because some dead vultures probably died away from the areas that were searched or were removed by scavengers. Breeding success did not appear to be unusually low, compared with that of other Gyps species.

Both the high rate of the vulture population declines and the high directly observed death rate of adults and sub-adults indicated that an elevated mortality rate of full-grown vultures must be the main demographic mechanism of the decline. Whether or not reduced breeding success, other than that associated with adult mortality, was also involved was not clear. However, these findings were sufficient to suggest that finding the most frequent cause of death of vultures would be the key to diagnosing the cause of the population declines.

\section{Causes of death}

Vultures at Keoladeo National Park were observed looking ill with drooping necks for uncharacteristically protracted periods (Prakash 1999). In 1999 two OWBV were collected by 
BNHS and sent for post-mortem examination at the Indian Wildlife Cooperative (North Division) at Hisar Veterinary College. One bird was seen to fall from a tree close to Keoladeo National Park, from where it was recovered alive but died soon thereafter, and the second was found dead in the city of Delhi. The only unusual post-mortem finding was visceral gout, an accumulation of uric acid crystals in the tissues. Extensive renal gout was evident in both birds and was considered to have been the proximate cause of death. In both cases, the renal gout was acute with extensive tissue destruction. There are several possible aetiologies of visceral gout, including abnormally high protein diet, primary renal failure and dehydration, but no causal factor was identified at this stage (Cunningham 2000).

Further investigations of causes of vulture deaths in India were hampered because few fresh vulture carcasses were available for examination. This was largely due to the lengthy procedure required before permits to collect dead birds were issued. In 2000, the three Gyps species endemic to the Indian subcontinent were listed as 'Critically Endangered' by IUCN. Later, they were also placed on Schedule 1 of India's Wildlife Protection Act (1972), further increasing the difficulty of obtaining permits to collect dead birds. This often resulted in vulture carcasses rotting or being removed by scavengers before they could be collected, and between February 2000 and June 2001, only eight dead vultures were collected from the large numbers of carcasses encountered. Hence, legislation intended to protect vultures and other wildlife inadvertently hindered the process of identifying the cause of declines. Post-mortem examinations were initially conducted at the Poultry Diagnostic and Research Centre (PDRC) in Pune, India, and six of eight birds collected were found to have visceral gout (Cunningham et al. 2003). The BNHS consortium also engaged the Australian Animal Health Laboratory (AAHL), expert in the identification of novel diseases, to help identify the causes of decline, although permits were only given for the export of a very small number of samples, again after a very lengthy application process.

Investigations in India were made possible by funding to the BNHS consortium from the UK government's Darwin Initiative grant scheme. As part of this programme, a captive care centre for vultures was set up to aid in diagnostic work and develop the capacity for vulture husbandry should conservation breeding become necessary. The centre was established in 2001 in collaboration with the Forest Department of Haryana at Pinjore and was opened in 2003 by Elliot Morley, then under secretary of State for the Environment in the UK government. Although the centre provided excellent facilities for post mortem examinations, the number of vulture carcasses collected remained low. Despite these small numbers, it remained clear that a high proportion of carcasses showed evidence of visceral gout. Of 13 OWBV from India and Nepal examined by February 2004, 10 (77\%) had gout. Of 12 LBV, $8(67 \%)$ had gout (Shultz et al. 2004).

The TPF/OSP group collected larger numbers of dead OWBV in Pakistan. Post mortem analyses of an initial sample of 36 birds found that $58 \%$ had renal failure as indicated by the presence of visceral gout, but exhaustive analyses failed to find its cause (Oaks et al. 2001). Later studies of much larger samples confirmed this high proportion of visceral gout in OWBV in Pakistan, with the highest prevalence $(>80 \%)$ being found in adult and subadult birds (Oaks et al. 2004a, Gilbert et al. 2006). Both the BNHS consortium and the TPF/OSP group looked hard for the causes of renal damage and for other causes of death. The teams identified novel vulture pathogens. A mycoplasma was isolated from an OWBV in Pakistan (Oaks et al. 2004b) and the AAHL isolated a herpes virus from an LBV from India (Cardoso et al. 2005). However, there was nothing to suggest that either of these played any part in the declines. Extensive analyses of tissues of dead vultures collected in Pakistan for a wide range of toxic environmental pollutants, including heavy metals, organophosphorus and organochlorine compounds and carbamates, failed to find significant numbers of birds contaminated at concentrations likely to have caused death (Oaks et al. 2001, 2004a).

In late 2002, the cause of the vulture declines was still eluding all of the researchers. A likely cause seemed to be an infectious disease (Pain et al. 2003, Cunningham et al. 2003). There was 
some evidence that declines had spread geographically. They were first noted in Rajasthan, Uttar Pradesh and Delhi, subsequently reported from other parts of India, and later reported from Pakistan and Nepal. This difference in timing may have been because of a spread in awareness and thus reporting of the problem. However, good populations of vultures remained in Pakistan in 1999-2000, where they were reported to have started to decline only within the previous two or three years (Khan et al. 2001), whereas vulture populations in most of India were already severely depleted by then (Prakash et al. 2003, 2005a). Numbers of OWBV in Pakistan then declined very rapidly (Gilbert et al. 2002). Work conducted in Pakistan in 2000 also found that the proportion of birds exhibiting neck or head-drooping behaviour, similar to that reported by Prakash (1999) for sick birds at Keoladeo National Park, was highest near the Indian border, as were numbers of dead birds, and this was interpreted as a westward spread in the factors responsible for the decline (Khan et al. 2001). Head or neck-drooping was considered to be a relatively uncommon behaviour in vultures in South Asia (Prakash et al. 2003, Riseborough and Virani in Khan et al. 2001), and appears to be exhibited when vultures are sick or weak (Prakash et al. 2003; Bahat, in Katzner and Parry-Jones 2001) and during periods of extremely hot weather (Camiña 2001, Gilbert et al. 2007a). Whilst some considered this a noteworthy behaviour, potentially indicative of sick birds (Prakash et al. 2003), others suggested that this may actually have low specificity and sensitivity as an indicator of poor health (Gilbert et al. 2007a).

Although these observations were consistent with the spread of an infectious disease from India to Pakistan, there were also other possible explanations (e.g. Cunningham et al. 2003). The main reason that it was felt that infectious disease could have been the cause of the vulture declines was that other plausible explanations had been checked and found to be improbable. Although no pathogen had been identified as the cause, it was well known that finding such agents and demonstrating their effects is difficult. Hence, it seemed probable that continued work would uncover the pathogen. In fact, as subsequent events were to show, the same line of reasoning can be applied to novel environmental pollutants.

\section{The diclofenac breakthrough}

In 2003 the TPF/OSP team, working in Pakistan, conducted a survey of 74 veterinarians and veterinary pharmaceutical retailers to identify livestock drugs that were known to be toxic to bird and mammal kidneys and capable of being absorbed after ingestion. Non-steroidal antiinflammatory drugs (NSAIDs) are known to be potentially nephrotoxic in mammals, with toxicity varying among drugs and species, and even between individuals (Hersh et al. 2005; Fletcher et al. 2006; Gooch et al. 2007). Several NSAIDs have been reported to cause renal disease in birds (Nys and Rsaza 1983, Klein et al. 1994). The only NSAID identified as being in widespread use was diclofenac, which was used to reduce pain, inflammation and fever in livestock. It had been available for veterinary use in Pakistan only since 1998. In India however, diclofenac appears to have been available since circa 1990, and 19 of 23 veterinarians interviewed indicated that they had been using the drug since 1993-1994 or earlier (BNHS/RSPB unpublished data).

The team analysed kidney samples from 38 OWBV found dead in Pakistan between 2000 and 2002, and found that all of 25 birds that died with visceral gout had detectable diclofenac residues in the kidney. By contrast, none of 13 birds that died without visceral gout had detectable diclofenac (Oaks et al. 2004a). Oaks's team then established the toxicity of diclofenac to OWBVs experimentally by administering high and low diclofenac oral doses to two groups of two captive OWBVs, and then by feeding 20 OWBVs with meat from ungulates treated shortly before death with a standard veterinary dose of diclofenac. The vultures were affected by the diclofenac in a dose-dependent way. Death occurred rapidly in all of the birds exposed to high doses and many of those given low doses. In all cases, the dead birds had visceral gout. Histological examination 
revealed kidney damage similar to that found in the carcasses of wild vultures with gout (Oaks et al. 2004a). It is not known how diclofenac causes renal failure, although a mechanism has been proposed (Meteyer et al. 2005).

Oaks and colleagues announced their preliminary findings as soon as they became available, at a conference in Hungary in May 2003, well in advance of publication. This was crucial, as it helped to speed up the process of checking whether the situation revealed so convincingly for OWBV in Punjab province, Pakistan, also held for other vulture species and across the wider area of the Indian subcontinent from which catastrophic vulture declines had been reported.

The BNHS team moved rapidly to analyse frozen tissues collected from dead vultures found in India and Nepal. As had been found in Pakistan, all of the vultures with visceral gout had detectable diclofenac in the kidneys or liver whilst none of the birds with no sign of gout were contaminated (Shultz et al. 2004). This was the case for both OWBV and LBV and a high proportion of both species exhibited visceral gout. These results, taken together with those of Oaks et al. (2004a) indicated that diclofenac was associated with the rapid vulture declines being observed in all parts of the subcontinent. However, it was not yet clear that there was sufficient diclofenac in the vultures' food supply to fully account for the catastrophic declines. Many scientists were sceptical and felt it unlikely that diclofenac alone could explain such large effects (Proffitt and Bagla 2004).

\section{The case that diclofenac is the major or sole cause of the vulture declines}

There seemed to be good reasons to question whether diclofenac could be the sole cause of the vulture declines and the RSPB, BNHS and colleagues went on to investigate whether there was any foundation to this scepticism. NSAIDs tend to have short residence times in mammalian tissue, including ungulates. In European cattle Bos taurus that receive standard veterinary doses of diclofenac, tissue levels decline to undetectable levels after about a week (EMEA 2004, Green et al. 2006). Hence, it seemed that an improbably large number of animals would have to be treated with diclofenac just before they died to pose a serious threat to vultures. A possible explanation might be that diclofenac is metabolised more slowly in Indian cattle Bos indicus than in European cattle. However, experiments showed that this was not the case. Tissue concentrations of diclofenac, taken from experiments in which Indian and European cattle were killed at different intervals after dosing (Taggart et al. 2006, EMEA 2004), were used to calculate diclofenac concentrations averaged across all the edible tissues of a carcass at different times after treatment. A dose-response model of the toxicity of diclofenac to OWBV was derived from the experiments of Oaks et al. (2004a) and used to estimate the proportion of vultures that would be killed by a large meal of mixed tissues from a carcass in relation to the time of treatment and the cow's death. The average diclofenac concentration in edible livestock tissues was sufficient to kill more than $10 \%$ of vultures feeding from the carcass of an animal treated with diclofenac only within a day or two of treatment (Green et al. 2006). The rate of decline of tissue concentrations and differences among tissues were similar for European and Indian cattle and there were indications that a similar pattern is found in Water Buffalo Bubalus bubalis.

In order to establish the proportion of livestock carcasses that would need to contain concentrations of diclofenac lethal to vultures to have caused the observed population crash, Green et al. (2004) developed a simulation model of a vulture population using demographic rates based upon the scientific literature and expert opinion. The model assumed that the population of full-grown vultures was exposed to a risk of death from diclofenac poisoning every time they fed, because a proportion of ungulate carcasses contained a lethal concentration of the drug. These deaths were assumed to elevate mortality rates and to reduce breeding success when parent birds are killed. Using a range of plausible assumptions about normal mortality rates and intervals between meals, it was shown that less than $1 \%$ of livestock carcasses $(0.13-0.75 \%$, depending upon the vulture species, population and model parameter values) would have to carry lethal concentrations of diclofenac to have caused the observed rates of OWBV and LBV 
population decline in India and Pakistan between 2000 and 2003. The model was also used to calculate the proportion of dead adult and subadult vultures that would have visceral gout, the characteristic sign of diclofenac poisoning, if the observed declines were caused only by diclofenac. It was found that the proportion of dead vultures observed to have gout in Pakistan and India was consistent with diclofenac being the most important cause of the decline, and perhaps its only cause, in both Pakistan and India and for both OWBV and LBV.

These analyses demonstrated that a sufficiently high proportion of dead vultures showed signs of diclofenac poisoning to account for the declines and that the proportion of contaminated ungulate carcasses need only be low. However, they do not show that sufficient ungulate carcasses really are contaminated with high enough diclofenac concentrations to cause the declines. The only way to do that convincingly was to collect tissue samples from a representative sample of dead domesticated ungulates from many sites across India. The BNHS team, in collaboration with the Wildlife Institute of India (WII), collected 1,848 liver samples from domesticated ungulates from carcass dumps from 67 sites across 12 states in India, between May 2004 and June 2005. Results of diclofenac analyses revealed that $10.1 \%$ of carcasses had detectable concentrations. Diclofenac was found in cattle, water buffaloes, goats and horses, but not sheep. All states showed evidence of contamination except one in which only one site was sampled (Taggart et al. 2007). These observed concentrations were then used, in combination with the dose-response toxicity model and the vulture population model described above, to estimate the rate of population decline expected for a population of OWBV with this level exposure. The expected rate of decline was $80-99 \%$ per year, depending on model assumptions, which is more than, and not significantly different from, the rate of population decline ( $48 \%$ per year) estimated from road transect surveys carried out a few years before (Green et al. 2007). Hence, there was sufficient diclofenac in ungulate carcasses available to vultures in India to cause their populations to decline at the observed rate without the need to invoke any other causes. Studies in Pakistan estimated the proportion of diclofenac contaminated ungulate carcasses encountered by OWBV by identifying clusters in space and time of vultures killed by diclofenac (Gilbert et al. 2006). This research indicated that contamination was sufficient to account for the population decline and that variation among colonies and years in the rapidity of decline was strongly correlated with the mortality rate caused by diclofenac.

\section{The scale of diclofenac use in India}

Diclofenac is no longer covered by patent and more than 50 companies in India manufactured veterinary formulations. Across the subcontinent, it appears to have been the welfare drug of choice for veterinarians treating livestock for a range of conditions. It is generally administered as an intramuscular injection, although an ingestible bolus form also exists. It is likely to be useful in a range of situations, including in rural communities, where families frequently keep water buffalo and cattle for working the land and for milking. As a potent anti-inflammatory drug, diclofenac can help to temporarily alleviate the effects of a range of veterinary problems (e.g. muscle inflammation in the limbs, and mastitis) and so potentially render domestic livestock more able to continue to work productively or yield milk.

Prakash et al. (2005 b) estimated that if $10-20 \%$ of the estimated 503 million livestock in India die annually and become available to vultures (only a small proportion are eaten by people), then a pharmaceutical industry estimate of 5 million annual diclofenac treatments would result in 5$10 \%$ of carcasses being contaminated with detectable concentrations of diclofenac. However, given the short residence time of diclofenac, this would only be the case if all treated animals died within a week of being given diclofenac. The observed 10\% diclofenac prevalence in samples from carcasses of domesticated ungulates (Taggart et al. 2007) suggests that considerably more than the estimated 5 million courses of treatment are given annually, and/or that the majority of animals treated are fatally ill. 


\section{Finding practical ways to prevent the extinction of South Asian vultures}

In January 2004, as soon as the initial case for the importance of diclofenac in causing vulture declines had been assembled and tested, a group of conservation bodies, including both the BNHS and TPF/OSP groups, issued a Manifesto. This called for immediate action from the governments of all Gyps vulture range states to prevent the veterinary use of diclofenac. In February 2004, two important international meetings were held to review the scientific evidence, present the emerging consensus to government representatives and to initiate the planning of conservation action. The first was a Vulture Summit in Kathmandu, which was convened by TPF and BCN and the second was an International South Asian Recovery Plan Workshop convened by the BNHS group (ISARPW 2004). Participants included NGOs, governmental organisations and others from across South Asia and internationally. Two key recommendations emerged from these meetings and were presented in the report of the International South Asian Recovery Plan Workshop. These were (I) that government authorities in all range states introduce legislation or regulations to prevent all veterinary uses of diclofenac that pose a risk to vultures, and (2) that captive populations of all three affected Gyps species be established immediately in South Asia, for the purposes of conservation breeding and subsequent reintroduction to a diclofenac-free environment.

The captive care facilities developed in India in 2001 were converted into a conservation breeding facility in 2004. These have now been expanded, and additional facilities have been constructed by BNHS in West Bengal and Assam. These three centres currently (as of $15^{\text {th }}$ April 2008) hold 83 OWBV, 71 LBV and 28 SBV. The aim of the conservation-breeding programme in India is to hold a minimum of 25 pairs of each species at each of a minimum of three sites. In Pakistan, a facility, holding II OWBV, is run by the World Wide Fund for Nature (WWF) Pakistan and the Punjab Wildlife and Parks Department of the Provincial Government, with support from The Hawk Conservancy Trust and the Environment Agency of the United Arab Emirates. In Nepal, a facility is being developed by the National Trust for Nature Conservation, the Department of National Parks and Wildlife Conservation and Bird Conservation Nepal, supported by RSPB and ZSL. It holds 14 OWBV.

Given the widespread use of diclofenac, and the evident importance of veterinary use of this drug across South Asia, it soon became apparent that an alternative NSAID, of low toxicity to vultures and effective for the treatment of livestock, would need to be found to facilitate and expedite a diclofenac ban. As an initial step, a questionnaire was sent to veterinarians at zoos and wildlife rehabilitation centres globally to ask which NSAIDs they had used to treat scavenging birds, and the clinical outcome. Survey results identified the NSAID meloxicam as a potential alternative. Meloxicam had been given to 39 Gyps vultures from six species and at least 700 individuals from 54 other raptor and scavenging bird species with no ill effects. However, mortality with associated kidney damage (gout and/or renal failure) was reported with the use of several other NSAIDs, including flunixin and carprofen (Cuthbert et al. 2006b).

Subsequently, a comprehensive safety-testing programme for meloxicam was initiated in South Africa, as a collaboration between South African (Pretoria University and DeWildt Cheetah and Wildlife Trust), Namibian (Rare and Endangered Species Trust), Indian (BNHS, Indian Veterinary Research Institute) and UK (RSPB, Aberdeen University, Cambridge University) research and conservation groups. The threatened South Asian Gyps species could not be used for initial testing because they were essential to the captive breeding programme and it was therefore necessary to find a surrogate species. An obvious candidate was the African White-backed Vulture (AWBV), Gyps africanus, which is not considered to be threatened, being classified in the 'Least Concern' category by IUCN (IUCN 2007). Captive, injured or nonreleasable AWBV were used to assess whether the toxicity of diclofenac to this species was similar to that of OWBV. Four AWBV were used for an experiment in which two were randomly selected and given $0.8 \mathrm{mg} \mathrm{kg}^{-1}$ of diclofenac by gavage and two were sham dosed with sterilised water. The dose was selected using the dose-response model previously established for 
OWBV. If diclofenac were as toxic to AWBV as it is to OWBV then there was a less than $1 \%$ chance that both of the treated birds would survive. The two diclofenac-treated birds died within two days with visceral gout, whilst the untreated controls remained healthy (Swan et al. 2006a).

The meloxicam safety testing trial on AWBV was implemented in stages to avoid unnecessary deaths if the drug proved to be toxic. The maximum likely level of exposure (MLE, $1.5 \mathrm{mg} \mathrm{kg}^{-1}$ body weight) to meloxicam in the wild was first estimated, based upon known concentrations in the tissues of experimentally treated livestock and vulture food intake. At each stage of the experiment, the dose of meloxicam administered by gavage was increased until the MLE was exceeded. Eventually, a dose of $2.0 \mathrm{mg} \mathrm{kg}^{-1}$ body weight was administered to a sample of 40 AWBV. All birds survived these treatments with no obvious ill effects, and serum uric acid concentration, which is greatly elevated in OWBV, AWBV and Eurasian Griffons treated with diclofenac (Oaks et al. 2004a, Swan et al. 2006a), remained within normal limits. Next, an experiment was performed in which captive AWBV were fed tissues from cattle treated just before slaughter with a higher than standard veterinary course of meloxicam. All of the six treated AWBV remained healthy with normal serum uric acid concentrations. Finally, ten individuals from two of the threatened Asian vulture species (OWBV and LBV) were given meloxicam by gavage, five of them at a dosage above the MLE. All survived with no obvious ill effects, as did 21 birds (OWBV and LBV) fed muscle or liver tissue from water buffalo treated with double the standard veterinary dose of meloxicam until eight hours before slaughter (Swan et al. 2006b, Swarup et al. 2007). The results of these studies suggested that meloxicam is of low toxicity to Gyps vultures, and that in this respect it would be a suitable substitute for diclofenac. Meloxicam also appears to have very low toxicity to a wide range of other raptors and scavenging birds that may encounter carcasses, with over 700 individuals from 54 species clinically treated with meloxicam and a further five species dosed with meloxicam at dosages above MLE (Cuthbert et al. 2006b, Swarup et al. 2007). Like diclofenac, meloxicam is out of patent, licensed for veterinary use in India, already produced for veterinary use in injectable and bolus (ingestible) form, and considered a very effective NSAID (Noble and Balfour 1996, Del Tacca et al. 2002, Deneuche et al. 2004) used to treat a variety of livestock ailments (Friton et al. 2004, Hamman and Friton 2003, Milne et al. 2003).

In November 2004, BNHS, with support from RSPB, initiated an advocacy programme in India to promote a ban on the use of diclofenac. Throughout the various phases of meloxicam safety testing, the researchers fed results through the advocacy programme to keep the Indian authorities fully informed of preliminary research findings. A preliminary report was made available to relevant government officials, and on 17 March 2005, Board Members of the National Board for Wildlife recommended a ban on the veterinary use of diclofenac. The Indian Ministry of Environment and Forests adopted a constructive approach and held a two-day international conference early in 2006. This meeting coincided with publication of the first meloxicam safety testing results (Swan et al. 2006b). A series of recommendations were produced during the meeting, of which the first was 'to strongly recommend to the Governments of the respective countries to take immediate steps to completely phase out veterinary diclofenac' (MoEF 2006). In May 2006, a directive from the Drug Controller General of India was circulated to relevant officials for withdrawal of manufacturing licences for veterinary diclofenac. The Government of Nepal took similar action in August 2006, shortly followed by the Government of Pakistan.

The governments of these countries are to be commended on the rapidity with which this action was taken. A two and a half year interval between identifying veterinary diclofenac as the cause of declines and banning its production may appear far too long given the annual vulture decline rates, but it is rapid in comparison with many other efforts to resolve environmental problems. The widespread use of DDT from the mid-1940s onwards was identified as the cause of significant mortality, reduction of breeding success and population declines of birds and other non-target species by the early 1960s (Barnett 1950, Mohr et al. 1951, Hickey and Hunt 1960, Wurster et al. 1965, Ratcliffe 1967). However, it was not until 1972 that the majority of uses of 
DDT were banned in the USA (Blus 2003) and 1986 before DDT was effectively banned in the UK (Pesticides Safety Directorate; http://www.pesticides.gov.uk/approvals.asp?id=55).

Whilst the current bans on the manufacture of veterinary diclofenac are essential, much remains to be done to ensure that the affected species do not disappear from South Asia. Retail sale of veterinary diclofenac is still legal in India, and diclofenac is still being sold and used 9 months after the ban (authors' unpublished information). Awareness campaigns, incentives for meloxicam use and a ban on retail sale and use of veterinary diclofenac are likely to be necessary to bring diclofenac contamination of domestic ungulate carcasses down to the very low levels required for the safety of wild vultures. The use on livestock of diclofenac formulated for human use is also a possible barrier to the full removal of diclofenac from vulture food supplies. Adequate monitoring is essential, both of the availability of veterinary diclofenac and its use. The latter is best performed through carcass sampling as described by Taggart et al. (2007), with the impact upon vultures of the observed level of contamination being assessed by modelling (Green et al. 2007). The rapidity of vulture declines and the uncertainty about when diclofenac contamination will be removed make the establishment of conservation breeding centres a continuing necessity. In situ conservation measures in combination with conservation advocacy and awareness programmes may also be necessary to help ensure that at least some of the small remaining vulture populations remain extant. Two in situ measures have been proposed to reduce mortality in the wild; the exchange of diclofenac for meloxicam in areas surrounding breeding colonies, and, in Nepal, diversionary feeding with diclofenac-free carcasses. The efficacy of these measures will depend upon the availability of alternative food sources, the extent of use of diversionary feeding stations, and bird movements within and outside the breeding season. Little is known of movements in Asian Gyps species. Throughout Africa and Europe, Gyps species can be sedentary, nomadic, partially migratory or migratory, with movement patterns varying between regions and apparently in relation to seasonal resource availability (Bernis 1983, Mundy et al. 1992). In general, adult birds appear to be more sedentary, and juvenile and immature birds more migratory or dispersive in nature. However, preliminary results from satellite-tagged OWBV in Nepal indicate that even adult birds can pass a high proportion of the non-breeding season distant from breeding sites (R. Cuthbert and H. S. Baral unpublished data). Satellite tagging studies of 5 non-breeding adult OWBV in Pakistan found that the maximum distance travelled from the colony varied considerably between individuals, ranging from 35 to $316 \mathrm{~km}$, and home range areas varied from 1,824 to $68,930 \mathrm{~km}^{2}$ (Gilbert et al. 2007b).

Food provisioning near a colony of OWBV in Pakistan during the 2003-04 breeding season illustrated that the provision of clean food appeared to be able to reduce, but not eliminate, mortality from diclofenac (Gilbert et al. 2007b). There was also considerable seasonal variation in the extent to which vultures used the diversionary food, with the vulture restaurant visited on, only $16 \%$ of days and by a relatively small number of birds at the end of the breeding season compared with $74 \%$ of days by a far larger number of birds earlier in the season. There were significant declines in mortality when vultures were fed clean food, but no reduction in the rate at which numbers of breeding pairs (active nests) declined at the colony in the year following the diversionary feeding ( 298 nests in 2002-03, 203 nests in 2003-04 and 118 nests in 2004-05, AVPP 2007). These results show that, whilst food provisioning may be of some benefit, it did not prevent the population from declining. Whilst the impact of year-long food provisioning remains untested, it is likely to have a greater impact on vulture survival in areas where alternative food is scarce, in colonies where a high proportion of birds tend to be sedentary, and where local diclofenac use is minimal or non-existent.

The impact on vulture populations of exchanging supplies of meloxicam for those of veterinary diclofenac is also untested, although exchange programmes are underway in Nepal, in combination with year round provisioning of safe food. Careful monitoring of the effectiveness of these programmes in reducing the rates of declines at colonies will inform future in-situ activities. 


\section{Wider implications of NSAID use}

The known toxicity of diclofenac to four Gyps species (G. bengalensis, G. indicus, G. fulvus and G. africanus; Oaks et al. 2004a, Shultz et al. 2004, Swan et al 2006a), and the phylogenetic position of these species each forming a sister relationship with one or more of the remaining Gyps species (Johnson et al. 2006) suggest that all members of the Gyps genus are likely to be sensitive to diclofenac. However, the NSAID survey that initially identified meloxicam as a potential alternative for diclofenac (Cuthbert et al. 2006b) also highlighted two additional issues of concern. First, diclofenac was not the only NSAID to have been associated with gout and/or renal failure in treated birds, and second, Gyps vultures were not the only bird species to be affected. Five of 40 birds given carprofen died (with doses from $1.0-5.0 \mathrm{mg} \mathrm{kg}^{-1}$ ), and seven of 24 birds administered flunixin died (with doses from $0.5-12.0 \mathrm{mg} \mathrm{kg}^{-1}$ ) with renal failure and/or gout, along with one bird given ibuprofen and one phenylbutazone at unknown dose levels. Both carprofen and flunixin are used to treat livestock in Europe, although not yet in South Asia, and information on residues of these NSAIDs in livestock tissues suggests that livestock dying shortly after treatment could contain sufficient residues to pose a threat to scavenging birds (Cuthbert et al. 2006b).

Species that died following treatment with these NSAIDs included Gyps vultures, a Harris's Hawk Parabuteo unicinctus, Northern Saw-whet Owl Aegolius acadicus, Red-legged Seriema Cariama cristata, Marabou Stork Leptoptilos crumeniferus, Cinereous Vulture Aegypius monachus and a Lappet-faced Vulture Torgus tracheliotus. The diversity of species affected suggests that the veterinary use of some NSAIDs may pose a problem for scavenging birds of other species and in other areas. However, preliminary results suggest that some species, including at least one New World vulture, appear particularly insensitive to the effects of diclofenac (B. Rattner et al. in press). Whilst the situation in India is unique, in that vast numbers of domestic livestock remain in the open after death, any situation in which recently treated livestock can be scavenged by birds presents a potential problem.

More work is urgently needed on the risks that NSAIDs pose to scavenging birds globally. Governments should only licence NSAIDs for veterinary use if they have first been tested and found to be sufficiently safe to scavenging birds likely to feed on the carcasses of treated animals.

It is possible that diclofenac use in India has resulted in mortality in a wider range of species than Gyps vultures. A lack of monitoring has made this difficult to investigate, but repeated surveys of Red-headed Sarcogyps calvus and Egyptian Neophron percnopterus Vultures have shown that these species have declined rapidly across India, though apparently with a later onset than Gyps vultures (Cuthbert et al. 2006a). As no carcasses of these species have been collected and analysed, it is not possible to determine the role that diclofenac may have played in their declines.

\section{Concluding comments}

The investigations described here have some interesting features. Quantification of the scale of the declines and estimation of minimum mortality rates by carcass searching were important in establishing elevated adult mortality as the main demographic mechanism of the declines. However, because of the absence of widespread bird population monitoring, it proved difficult to measure the declines and identify when and where they began. The mobilisation of scientific effort was rapid, once the declines had been recognised, but wildlife protection legislation, though essential in other contexts, was an obstacle to identifying the cause of elevated mortality. The engagement of a diversity of researchers from several countries and scientific disciplines and from academic institutions, NGOs and government agencies was vital. Their organisation into separate research groups, which were conducting complementary research, in competition, but also in communication with one another, was a stimulus to progress and rigorous evaluation of hypotheses. 
Once the cause was identified, the international research and conservation community, and the Indian Ministry of the Environment and Forests, closely followed by the authorities in Nepal and Pakistan, pulled together with remarkable rapidity and determination to find a solution to the problem. This international collaborative effort was exceptional, with academics setting aside their research agendas to give priority to this work alongside conservation scientists, advocates, civil servants and politicians. Conservation NGOs played a central role in arguing for action and in funding and designing relevant research. Considerable progress has already been made, but saving Asian vultures remains a daunting challenge, requiring effort and vigilance for decades to come. Establishing viable captive populations, removing diclofenac from the vulture food supply in the Indian subcontinent and preventing its replacement by other toxic NSAIDs are the main short-term priorities. Maintaining and breeding vultures in captivity for reintroduction, restoring wild populations and preventing future adverse impacts of NSAIDs and other veterinary drugs are tasks for the longer term.

\section{Acknowledgements}

We wish to express our appreciation of the contribution of the late Bill Burnham, former president of The Peregrine Fund, to efforts to save the vultures of South Asia. We thank Mark Avery, Alistair Gammell, David Houston, Georgina Mace, Ian Newton and Stephen Piper for advice and help, and David Gibbons for comments on the manuscript. We would like to thank the Indian Veterinary Research Institute and the Indian Council of Agricultural Research, the Indian Ministries of Environment and Forest, Agriculture, Health, and the Drug Controller General of India, the governments of Haryana, West Bengal and Assam states, and the governments of Nepal and Pakistan for all of their help and support. Many thanks to the Poultry Diagnostic and Research Centre, Pune, India, and especially Dr Ghalsasi, for collaborative work and analyses. The RSPB, BNHS and ZSL would like to thank the UK government for funding provided under the Darwin Initiative for the Survival of Species, the British High Commission, New Delhi, the British High Commission Global Opportunities Fund, The Earth Matters Foundation, the Rufford Foundation and many individual donors. Funding for work conducted by The Peregrine Fund was provided by the Gordon and Betty Moore Foundation, The Peregrine Fund, Disney Wildlife Conservation Fund, the UN, Summit, and Ivorybill Foundations, Zoological Society of San Diego, and other important donors. Finally, we thank all of the institutions to which the authors are affiliated for their financial and other support.

\section{References}

AVPP (2007) Asian vulture population project, February 2007, www.peregrinefund. org/vulture

Baral, H. S., Giri, J. B. and Virani, M. Z. (2004) On the decline of Oriental Whitebacked Vultures Gyps bengalensis in lowland Nepal. Pp. 215-219 in R. D. Chancellor and B.-U. Meyburg, eds. Raptors Worldwide. Proceedings of the 6th world conference on birds of prey and owls. Berlin and Budapest: WWGBP and MME/Birdlife Hungary.

Barnett, D. C. (1950) The effect of some insecticide sprays on wildlife. Proc. Ann.
Conf. West. Assoc. State Game and Fish Comm. 30: 125 .

BirdLife International (2007) Species factsheet: Gyps coprotheres. Downloaded from http://www.birdlife.org on 21/6/2007

Bernis, F. (1983) Migration of the common Griffon Vulture in the Western Palaearctic. Pp. $185-196$ in S. R. Wilbur and J. A. Jackson, eds. Vulture biology and management. Berkeley and Los Angeles: University of California Press.

Blus, L. J. (2003) Organochlorine pesticides. Chapter 13 in D. J. Hoffman, B. A. Rattner, G. Allen Burton Jr and J. Cairns Jr, eds. 
Handbook of ecotoxicology. Boca Raton: Lewis CRC Press.

Camiña, A. (2001) The "head-drooping" behaviour in Spanish Eurasian griffon vulture populations. Preliminary results [abstract]. $4^{\text {th }}$ Eurasian Congress on Raptors, Pp. 34-35, Seville, Spain: Estación Biológica Donaña and Raptor Research Foundation.

Cardoso, M., Hyatt, A., Selleck, P., Lowther, S., Prakash, V., Pain, D., Cunningham, A. A. and Boyle, D. (2005) Phylogenetic analysis of the DNA polymerase gene of a novel alphaherpesvirus isolated from an Indian Gyps vulture. Virus Genes. 30: 371-81.

Cunningham, A. A. (2000) Investigation of vulture mortality in India: Report of a visit. Unpublished report to RSPB, Sandy, UK.

Cunningham, V., Prakash, D., Pain, G. R., Ghalsasi, G. A. H., Wells, G. N., Kolte, P., Nighot, M. S., Goudar, S. Kshirsagar and Rahmani, A. (2003) Indian vultures: victims of an infectious disease epidemic? Anim. Conserv. 6: 189-197.

Cuthbert, R., Green, R. E., Ranade, S., Saravanan, S., Pain, D. J., Prakash, V. and Cunningham, A. A. (2006a) Rapid population declines of Egyptian Vulture (Neophron percnopterus) and red-headed vulture (Sarcogyps calvus) in India. Anim. Conserv. 9: 349-354.

Cuthbert, R., Parry-Jones, J., Green, R. E. and Pain, D. J. (2006b) NSAIDs and scavenging birds: potential impacts beyond Asia's critically endangered vultures. Biol. Lett. 3: 90-93. doi:10.1098/rsbl.2006.0554.

Del Tacca, M., Colucci, R., Fornai, M. and Blandizzi, C. (2002) Efficacy and tolerability of Meloxicam a COX-2 preferential nonsteroidal anti-inflammatory drug. Clin. Drug Inv. 22: 799-818.

Deneuche, A. J., Dufayet, C., Goby, L., Fayolle, P. and Desbois, C. (2004) Analgesic comparison of meloxicam or ketoprofen for orthopaedic surgery in dogs. Vet. Surgery 33: 650-66o.

Duckworth, J. W., Salter, R. E. and Khounboline, K. (compilers) (1999) Wildlife in Lao PDR: 1999 status report. Vientiane: IUCN-The World Conservation Union / Wildlife Conservation Society /
Centre for Protected Areas and Watershed Management.

EMEA (2004) Committee for veterinary medicinal products: diclofenac. Summary Report, EMEA/MRL/885/o3-FINAL.

Fletcher, J. T., Graf, N., Scarman, A., Saleh, H. and Alexander, S. I. (2006) Nephrotoxicity with cyclooxygenase 2 inhibitor use in children. Pediatric Nephrology 21: 1893-1897.

Friton, G. M., Cajal, C., Romero, R. R. and Kleeman, R. (2004) Clinical efficacy of Meloxicam (Metacam ${ }^{\circledR}$ ) and Flunixin (Finadyne ${ }^{\circledR}$ ) as adjuncts to antibacterial treatment of respiratory disease in fattening cattle. Berliner und Munchener Tierarztliche Wochenschrift 117: 304-309.

Gilbert, M., Virani, M. Z., Watson, R. T., Oaks, J. L., Benson, P. C., Khan, A. A., Ahmed, S., Chaudry, J., Arshad, M., Mahmood, S. and Shah, Q. A. (2002) Breeding and mortality of Oriental White-backed Vulture Gyps bengalensis in Punjab Province, Pakistan. Bird Conserv. Internatn. 12: 311-326.

Gilbert, M., Oaks, J. L., Virani, M. Z., Watson, R. T., Ahmed, S., Chaudhry, M. J. I., Arshad, M., Mahmood, S., Ali, A., Khattak, R. M. and Khan, A. A. (2004) The status and decline of vultures in the provinces of Punjab and Sind, Pakistan: a 2003 update. Pp. 221-234 in R. C. Chancellor and B.-U. Meyburg, eds. Raptors Worldwide. Proceedings of the 6th world conference on birds of prey and owls. Berlin and Budapest: WWGBP and MME/Birdlife Hungary.

Gilbert, M., Watson, R. T., Virani, M. Z., Oaks, J. L. and Ahmed, S. et al. (2006) Rapid population declines and mortality clusters in three Oriental white-backed vulture Gyps bengalensis colonies in Pakistan due to diclofenac poisoning. Oryx 40: 388-399.

Gilbert, M., Watson, R. T. and Virani, M. Z. (2007a) Neck-drooping posture in oriental white-backed vultures (Gyps bengalensis): an unsuccessful predictor of mortality and its probable role in thermoregulation. $J$. Raptor Res. 41: 35-40.

Gilbert, M., Watson, R. T., Ahmed, S., Asim, M. and Johnson, J. A. (2007b) Vulture 
restaurants and their role in reducing diclofenac exposure in Asian vultures. Bird Conserv. Internatn. 17: 63-77.

Gooch, K., Culleton, B. F., Manns, B. J., Zhang, J. G., Alfonso, H., Tonelli, M., Frank, C., Klarenbach, S. and Hemmelgarn, B. R. (2007) NSAID use and progression of chronic kidney disease. Am. J. Med. 120 (3). doi:10.1016/j.amjmed.2006.02.015 MAR 2007.

Green, R. E. (1995) Diagnosing causes of bird population declines. Ibis 137: $\mathrm{S}_{47}-\mathrm{S}_{55}$ Suppl. 1.

Green, R. E. (2002) Diagnosing causes of population declines and selecting remedial actions. Pp. 139-156 in K. Norris and D. J. Pain, eds. Conserving bird biodiversity. Cambridge: Cambridge University Press.

Green, R. E., Newton, I., Shultz, S., Cunningham, A. A., Gilbert, M., Pain, D. J. and Prakash, V. (2004) Diclofenac poisoning as a cause of vulture population declines across the Indian subcontinent. $J$. Appl. Ecol. 41: 793-80o.

Green, R. E., Taggart, M. A., Das, D., Pain, D. J., Sashikumar, C., Cunningham, A. A. and Cuthbert, R. (2006) Collapse of Asian vulture populations: risk of mortality from residues of the veterinary drug diclofenac in carcasses of treated cattle. J. Appl. Ecol. 43: 949-956.

Green, R. E., Taggart, M. A., Senacha, K. R., Pain, D. J., Jhala, Y. and Cuthbert, R. (2007) Rate of decline of the oriental white-backed vulture Gyps bengalensis population in India estimated from measurements of diclofenac in carcasses of domesticated ungulates. PloS One 2(8) e686. doi:10.1371/journal.pone.0000686.

Griffith, R. T. H. (translator) $(1870-1874)$ Rámáyan of Válmíki. London: Trübner \& Co.. and. Benares: E. J. Lazarus \& Co. http:// www.sacred-texts.com/hin/rama/ryooo. htm

Grubh, R. B., Narayam, G. and Satheesan, S. M. (1990) Conservation of vultures in (developing) India. Pp. 360-363 in J. C. Daniel and J. S. Serrao, eds. Conservation in developing countries. Bombay: BNHS/OUP.

Hamman, J. and Friton, G. M. (2003) Clinical efficacy of non steroidal antiphlogistica in acute mastitis. Prakt. Tierarzt 84: 390 .
Hersh, E. V., Lally, E. T. and Moore, P. A. (2005) Update on cyclooxygenase inhibitors: has a third COX isoform entered the fray? Current Med. Res. and Opinion 21: 1217-1226.

Hickey, J. J. and Hunt, I. B. (1960) Initial song bird mortality following Dutch elm disease control programme. J. Wildl. Manage. 24: 259.

Hilton-Taylor, C. (2000) 200o IUCN Red List of Threatened Species. Gland, Switzerland, \& Cambridge, UK: IUCN/SSC.

Houston, D. (1974) Food searching behaviour in griffon vultures. Afr. J. Ecol. 12: 63-77.

Houston, D. (1985) Indian white-backed vulture Gyps bengalensis. Pp. 465-466 in I. Newton and R. D. Chancellor, eds. Conservation studies on raptors. Cambridge: International Council for Bird Preservation. Technical Publication No. 5 .

ILC (2003) Agricultural Statistics at a Glance 2003 and 17th Indian Livestock Census 2003. New Delhi: Dept. of Animal and Dairying, Ministry of Agriculture, Govt. of India.

ISARPW (2004) Report on the international South Asian recovery plan workshop. Buceros 9: 1-48.

IUCN (2007) 2007 IUCN Red List of threatened species. http://www.iucn.org

Johnson, J. A., Lerner, H. R. L., Rasmussen, P. C. and Mindell, D. P. (2006) Systematics within Gyps vultures: a clade at risk. BioMed Central Evol. Biol. 6: 65 doi:10.1186/1471-2148-6-65.

Katzner, T. and Parry-Jones, J., eds. (2001) Reports from the workshop on Indian Gyps vultures. 4th Eurasian Congress on Raptors, 25-29 September 2001, Pp. 4-6. Seville, Spain: Estación Biológica Doñana and Raptor Research Foundation.

Khan, A. A., Virani, M., Oaks, L., Benson, P. C., Gilbert, M., Watson, R. T. and Risebrough, R. W. (2001) A survey of the Oriental White-backed Vulture Gyps bengalensis in the Punjab Province, Pakistan. J. Research (Science) 12: 97-104.

Klein, P. N., Charmatz, K. and Langenberg, J. (1994) The effect of Flunixin meglumine (Banamine ${ }^{\circledR}$ ) on the renal function in northern bobwhite (Colinus virginieanusI): 
An avian model. Proc. American Assoc. Zoo Vet. 1994: 128-131.

Meteyer, C. U., Rideout, B. A., Gilbert, M., Shivaprasad, H. L. and Oaks, J. L. (2005) Pathology and pathophysiology of diclofenac poisoning in free-living and experimentally exposed oriental white-backed vultures (Gyps bengalensis). J. Wildl. Dis. 41: 707-716.

Milne, M. H., Nolan, A. M., Cripps, P. J. and Fitzpatrick, J. L. (2003) Assessment and alleviation of pain in dairy cows with mastitis. Cattle Pract. 11: 289-293.

MoEF (2006) Proceedings of the International Conference on Vulture Conservation. New Delhi: Ministry of Environment and Forests, Government of India.

Mohr, R. W., Telford, H. S., Peterson, E. H. and Walker, K. C. (1951) Toxicity of orchard insecticides to game birds in eastern Washington. Wash. Agric. Exp., Sta. Circ. 170: 22.

Mundy, P., Butchart, D., Ledger, J. and Piper, S. (1992) The vultures of Africa. London: Academic Press.

Newton, I. (1979) Population ecology of raptors. Berkhamsted, UK: Poyser.

Noble, S. and Balfour, J. A. (1996) Meloxicam. Drugs 51: 424-430.

Nys, Y. and Rzasa, J. (1983) Increase in uricemia induced by indomethacin in hens or chickens. C. R. Séances Acad. Sci. III. 296: 401-404.

Oaks, J. L., Rideout, B. A., Gilbert, M., Watson, R., Virani, M. and Khan, A. A. (2001) Summary of diagnostic investigations into vulture mortality: Punjab Province, Pakistan, 2000-2001 [Abstract]. $4^{\text {th }}$ Eurasian Congress on Raptors, 25-29 September 2001. Seville, Spain: Estación Biológica Doñana and Raptor Research Foundation.

Oaks, J. L., Gilbert, M., Virani, M. Z., Watson, R. T., Meteyer, C. U., Rideout, B., Shivaprasad, H. L., Ahmed, S., Chaudhry, M. J. I., Arshad, M., Mahmood, S., Ali, A. and Khan, A. A. (2004a) Diclofenac residues as the cause of vulture population decline in Pakistan. Nature 427: 630-633.

Oaks, J. L., Donahoe, S. L., Rurangirwa, F. R., Rideout, B. A., Gilbert, M. and Virani, M.
Z. (2004b) Identification of a novel mycoplasma species from an Oriental Whitebacked Vulture (Gyps bengalensis). J. Clinical Microbiol. 42: 5909-5912.

Pain, D. J. and Pienkowski, M. W., eds. (1997) Farming and birds in Europe: the Common Agricultural Policy and its implications for bird conservation. London: Academic Press.

Pain, D. J., Cunningham, A. A., Donald, P. F., Duckworth, J. W., Houston, D. C., Katzner, T., Parry-Jones, J., Poole, C., Prakash, V., Round, P. and Timmins, R. (2003) Gyps vulture declines in Asia; temporospatial trends, causes and impacts. Conserv. Biol. 17: 661-671.

Prakash, V. (1999) Status of vultures in Keoladeo National Park, Bharatpur, Rajasthan, with special reference to population crash in Gyps species. J. Bombay Nat. Hist. Soc. 96: 365-378.

Prakash, V., Pain, D. J., Cunningham, A. A., Donald, P. F., Prakash, N., Verma, A., Gargi, R., Sivakumar, S. and Rahmani, A. R. (2003) Catastrophic collapse of Indian white-backed Gyps bengalensis and longbilled Gyps indicus vulture populations. Biol. Conserv. 109: 381-390.

Prakash, V., Pain, D. J., Cunningham, A. A., Donald, P. F., Prakash, N., Verma, A., Gargi, R., Sivakumar, S. and Rahmani, A. R. (2005a) Corrigendum to "Catastrophic collapse of Indian white-backed Gyps bengalensis and long-billed Gyps indicus vulture populations" [Biol. Conserv. 109 (2003) 381-390] 124: 559.

Prakash, V., Green, R. E., Rahmani, A. R., Pain, D. J., Virani, M. Z., Khan, A. A., Baral, H. S., Jhala, Y. V., Naoroji, R., Shah, N., Bowden, C. G. R., Choudhury, B. C., Narayan, G. and Gautam, P. (2005b) Evidence to support that diclofenac caused catastrophic vulture population decline. Current Sci. 88: 2.

Prakash, V., Green, R. E., Pain, D. J., Ranade, S. P., Saravanan, S., Prakash, N., Venkitachalam, R., Cuthbert, R., Rahmani, A. R. and Cunningham, A. A. (2007) Recent changes in populations of resident Gyps vultures in India. J. Bombay Nat. Hist. Soc. 104: 129-135.

Proffitt, F. and Bagla, P. (2004) Circling in on a vulture killer. Science 306: 223. 
Rasmussen, P. C. and Parry, S. J. (2001) The taxonomic status of the "Long-billed" Vulture Gyps indicus. Vulture News 44: 18-21.

Ratcliffe, D. A. (1967) Decrease in eggshell weight in certain birds of prey. Nature 215: 208.

Rattner, B. A., Whitehead, M. A., Gasper, G., Meteyer, C. U., Link, W. A., Taggart, M. A., Meharg, A. A., Pattee, O. H. and Pain, D. J. (in press) Apparent tolerance of turkey vultures (Cathartes aura) to the non-steroidal anti-inflammatory drug diclofenac. Environmental Toxicology and Chemistry.

Ruxton, G. D. and Houston, D. C. (2004) Obligate vertebrate scavengers must be large soaring fliers. J. Theoret. Biol. 228: $431-436$.

Samant, J. S., Prakash, V. and Naoroji, R. (1995) Ecology and behaviour of resident raptors with special reference to endangered species. Final Report to the U.S. Fish \& Wildlife Service Grant No 14-160000990-1257. Mumbai: Bombay Natural History Society.

Sarrazin, F., Bagnolini, C., Pinna, J. L., Danchin, E. and Clobert, J. (1994) High survival of griffon vultures (Gyps fulvus fulvus) in a reintroduced population. Auk I11: 853-862.

Shultz, S., Baral, H. S., Charman, S., Cunningham, A. A., Das, D., Ghalsasi, D. R., Goudar, M. S., Green, R. E., Jones, A., Nighot, P., Pain, D. J. and Prakash, V. (2004) Diclofenac poisoning is widespread in declining vulture populations across the Indian subcontinent. Proc. Roy. Soc. Lond. $B$ (Supplement) 271 (Suppl 6): $\mathrm{S}_{458-\mathrm{S}_{4} 60 .}$ DOI: 10.1098/rsbl.2004.0223 (available online).

Srikosamatara, S. and Suteethorn, V. (1995) Populations of Gaur and Banteng and their management in Thailand. Nat. Hist. Bull. Siam Soc. 43: 55-83.
Swan, G. E., Cuthbert, R., Quevedo, M., Green, R. E., Pain, D. J., Bartels, P., Cunningham, A. A., Duncan, N., Meharg, A. A., Oaks, J. L., Parry-Jones, J., Shultz, S., Taggart, M. A., Verdoorn, G. and Wolter, K. (2006a) Toxicity of diclofenac to Gyps vultures. Biol. Lett. 2: 279-282. DOI: 1o/1098/rsbl.2005.0425.

Swan, G., Naidoo, V., Cuthbert, R., Green, R. E., Pain, D. J., Swarup, D., Prakash, V., Taggart, M., Bekker, L., Das, D., Diekmann, J., Diekmann, M., Killian, E., Meharg, A., Patra, R. C., Saini, M. and Wolter, K. (2006b) Removing the threat of Diclofenac to Critically Endangered Asian vultures. (2006) PLoS Biology. March 2006 4(3): e66.

Swarup, D., Patra, R. C., Prakash, V., Cuthbert, R., Das, D., Avari, P., Pain, D. J., Green, R. E., Sharma, A. K., Saini, M., Das, D. and Taggart, M. (2007) The safety of meloxicam to critically endangered Gyps vultures and other scavenging birds in India. Anim. Conserv. 10: 192-198.

Taggart, M. A., Cuthbert, R., Das, D., Pain, D. J., Green, R. E., Shultz, S., Cunningham, A. A. and Meharg, A. A. (2006) Diclofenac disposition in Indian cow and goat with reference to Gyps vulture population declines. Environ. Pollut. 147: 60-65.

Taggart, M. A., Senacha, K., Green, R. E., Jhala, Y. V., Ragathan, B., Rahmani, A. R., Cuthbert, R., Pain, D. J. and Meharg, A. A. (2007) Diclofenac residues in carcasses of domestic ungulates available to vultures in India. Environ. Internatn. 33: 759-765. doi:10.1016/j.envint.2007.02.010.

Thiollay, J.-M. (2006) The decline of raptors in West Africa: long-term assessment and the role of protected areas. Ibis 148: 240-254.

Wurster, C. F., Wurster, D. H. and Stickland, W. N. (1965) Bird mortality after spraying for Dutch elm disease with DDT. Science 148: 90 .

\section{DEBORAH J. PAIN*, CHRISTOPHER G. R. BOWDEN, RICHARD CUTHBERT, RHYS E. GREEN $^{1}$}

Royal Society for the Protection of Birds, The Lodge, Sandy, Bedfordshire, SG19 2DL, U.K.

${ }^{1}$ and Conservation Science Group, Department of Zoology, University of Cambridge, Downing Street, Cambridge CB2 3EJ, U.K. 
ANDREW A. CUNNINGHAM

Institute of Zoology, Zoological Society of London, Regent's Park, London NWI $4 R Y$, U.K.

DEVOJIT DAS, VIBHU PRAKASH, ASAD RAHMANI, SACHIN P. RANADE, KALU RAM SENACHA, S. SARAVANAN, NITA SHAH

Bombay Natural History Society, Hornbill House, Mumbai, 40oo23, India.

MARTIN GILBERT, RICHARD T. WATSON, MUNIR Z. VIRANI

The Peregrine Fund, 5668 West Flying Hawk Lane, Boise, Idaho 83709, U.S.A.

RAM D. JAKATI

Haryana Forest Department, Van Bhawan, sector 6, Panchkula, 134109, Haryana, India.

\section{YADVENDRADEV JHALA}

Wildlife Institute of India, Post Bag \#18, Chandrabani, Dehradun, 248001, Uttaranchal, India.

ALEEM A. KHAN

Ornithological Society of Pakistan, 109/D P.O. Box 73, Dera Ghazi Khan, Pakistan.

VINNY NAIDOO, GERRY SWAN

Department of Paraclinical Sciences, Faculty of Veterinary Science, University of Pretoria, Onderstepoort, South Africa.

\section{J. LINDSAY OAKS}

Department of Veterinary Microbiology and Pathology, Washington State University, Pullman, Washington 99164-7040, U.S.A.

JEMIMA PARRY-JONES

International Centre for Birds of Prey, Little Orchard Farm, Eardisland, Herefordshire HR6 9AS, U.K.

HEM SAGAR BARAL

Bird Conservation Nepal, P.O. Box 12465, Lazimpat, Kathmandu, Nepal.

DEVENDRA SWARUP

Indian Veterinary Research Institute, Izatnagar 243122, Uttar Pradesh, India.

MARK A. TAGGART

School of Biological Sciences, Dept of Plant \& Soil Science, University of Aberdeen, AB24 3 UU, U.K.

\section{KERRI WOLTER}

Rhino \& Lion Wildife Conservation NPO, "Vulture Programme", Kromdraai, South Africa.

* Author for correspondence; Director of Conservation, Wildfowl \& Wetlands Trust (WWT), Slimbridge, Glos GL2 7BT, U.K.; e-mail: Debbie.Pain@wwt.org.uk 